\title{
Effect of Isolation Techniques on Viability of Bovine Blood Neutrophils
}

\author{
P. SLÁMA ${ }^{1}$, Z. SLÁDEK ${ }^{1,2}$, D. RYŠÁNEK ${ }^{2}$ \\ ${ }^{1}$ Mendel University of Agriculture and Forestry in Brno, Czech Republic \\ ${ }^{2}$ Veterinary Research Institute, Brno, Czech Republic \\ Received October 24, 2005 \\ Accepted April 13, 2006
}

\begin{abstract}
Sláma P., Z. Sládek, D. Ryšánek: Effect of Isolation Techniques on Viability of Bovine Blood Neutrophils. Acta Vet Brno 2006, 75: 343-353.

The effect of selected isolation methods on the viability of neutrophil granulocytes (neutrophils) from the blood of healthy Holstein $\times$ Bohemian Red Pied crossbred heifers was evaluated. Two methods of neutrophil isolation were used: a) neutrophil isolation on the basis of hypotonic erythrocyte lysis (in two variants: after the erythrocyte lysis proper, the cells were centrifuged at either $200 \mathrm{~g}$ or $1000 \mathrm{~g}$ ), and b) neutrophil isolation with FACS Lysing Solution as the lysing agent. The viability of the isolated neutrophils was evaluated on the basis of apoptosis and necrosis. The results obtained with flow cytometry (FCM) suggest that, from the isolation techniques used, the method based on FACS Lysing Solution impaired the neutrophil viability least. After the application of this method, $5.36 \pm 2.15 \%$ of neutrophils were apoptotic and $0.51 \pm 0.12 \%$ were necrotic. In contrast, when the hypotonic erythrocyte lysis was used, the proportion of apoptotic neutrophils amounted to $42.14 \pm 7.12 \%$ and $49.00 \pm 14.70 \%$, respectively, and $41.12 \pm 5.55 \%$ and 36.91 $\pm 24.38 \%$ respectively of necrotic neutrophils $(P<0.01)$. This was also confirmed by the light microscopy. After the isolation with FASC Lysing Solution, $1.92 \pm 1.74 \%$ of neutrophils were apoptotic and $1.05 \pm 0.76 \%$ were necrotic, as distinct from after the hypotonic erythrocyte lysis where $9.43 \pm 3.69 \%$ of neutrophils were apoptotic and $12.67 \pm 4.74 \%$ of necrotic after centrifugation at $200 \mathrm{~g}$, while $12.60 \pm 4.35$ were apoptotic and $14.96 \pm 12.64 \%$ were necrotic after centrifugation at $1000 \mathrm{~g}$. It follows from the above-mentioned data that hypotonic lysis is not a suitable method for the isolation of neutrophils, as the method itself markedly affects cell viability.
\end{abstract}

Neutrophil, apoptosis, necrosis, phosphatidylserine, Annexin-V, propidium iodide, hypotonic erytrocyte lysis, FACS Lysing Solution, light microscopy, flow cytometry

Neutrophil granulocytes (neutrophils) constitute a significant component of the organism's non-specific defence system acting against bacterial infection, being the first line of cellular protection against invading microorganisms. After developing from the bonemarrow stem cells ( S mith 2000), they are subsequently released into the blood stream where they circulate for only 6 - 10 hours (Kuijpers and Roos 2001). Following chemotactic signals, they migrate from the blood space into the tissues where they function as phagocytes ( $\mathrm{Pa}$ a pe et al. 2003). There the neutrophils are active for 2 - 6 days, then they undergo apoptosis and are removed by the tissue macrophages (Kuijpers and Roos 2001) irrespective of whether their phagocytic capacity was used or not (Junqueira et al. 1997). Because of their unique importance in the body, the neutrophils have become the subject of a great number of scientific papers (Paape et al. 2003).

It is obvious that the study of these blood elements in vitro depends on the creation of suitable conditions that include, in particular, the most gentle isolation and high purity of cells. For this reason, methods were developed that, by means of physical or biochemical procedures, enable a quick and effective separation of the blood neutrophils for in vitro studies. The following techniques can be used for the isolation of neutrophils from the blood: hypotonic erythrocyte lysis (Carlson and Kaneko 1973; Duque et al. 1985; Van Oostveldt et al. 1999), erythrocyte lysis by $\mathrm{NH}_{4} \mathrm{Cl}$ (Roets et al. 1999; Van Oostveldt 
et al. 1999), neutrophil adhesion on a microscopic slide (Smith and Rommel 1977), isolation of bovine neutrophil granulocytes from peripheral blood based on centrifugation in a discontinuous metrizamide gradient (Hallen-Sandgren and Bjork 1988) or by means of biomagnetic beads (Soltys et al. 1999), Percoll density gradient isolation (Boyum 1968; Van Oostveldt et al. 1999; Cowland and Borregaard 1999; Soltys et al. 1999), erythrocyte lysis with FACS Lysing Solution (Chen et al. 1996; Carulli et al. 1998; Tay et al. 1998; Hodge et al. 1999; Storie et al. 2003). It is evident from this short overview that the neutrophils are exposed to not only physical manipulation but also to non-physiological conditions during the isolation. This may result in unwanted effect on basic biological properties of isolated cells. Van Oostveldt et al. (1999) drew attention to this fact in the sphere of veterinary biology. They used hypotonic erythrocyte lysis for the isolation of neutrophils, and they detected early stages of neutrophil apoptosis using only flow cytometry with labelled Annexin- $\mathrm{V}$ and propidium iodide according to Vermes et al. (1995). This method appears as very advantageous for the analysis of blood elements when a large number of samples are processed. Its disadvantage is the poor detection of early stages of apoptosis, which cannot be morphologically differentiated from normal cells. Thus it does not comprise the whole population of apoptotic cells. If conventional haematological methods, such as blood smears and their analysis, particularly by light microscopy are used, these early apoptotic neutrophils appear "invisible". Apoptosis, however, is a highly dynamic process and therefore one can expect the occurrence of apoptotic neutrophils with fully developed morphological features, such as the nucleus chromatin condensation, cell shrinkage, zeiosis, etc. in the population of isolated cells (Arends et al. 1990; DelVecchio et al. 1993; Granville et al. 1998; Reed 2000). It is thus obvious that, in addition to biochemical methods, also morphological characteristics specific for apoptosis must be analysed for the evaluation of the effect of isolation methods on neutrophil viability. Until now, however, it has not been known whether the isolation techniques also result in morphological manifestations of neutrophil apoptosis.

For these reasons, it was the aim of this work to prove whether the techniques of erythrocyte lysis cause not only biochemical but also, and in particular, morphological changes typical of apoptosis and necrosis of bovine blood neutrophils.

\section{Materials and Methods}

Animals and experimental design

The experiments were carried out in duplicate in four clinically healthy Holstein $\times$ Bohemian Red Pied crossbred virgin heifers aged 16 to 18 months. They were used as blood neutrophil donors for studies of isolation techniques effect. The experiments were designed to monitor the effect of two isolation techniques, namely the isolation of neutrophils using hypotonic erythrocyte lysis, and isolation based on the use of the FACS Lysing Solution. Signs of neutrophil apoptosis and necrosis were detected by light microscopy and flow cytometry.

Blood sampling

The blood $(150 \mathrm{ml})$ was drawn from the jugular vein into a sterile flask with an anticoagulant, namely Heparin (Léčiva a.s., Dolní Měcholupy, Czech Republic) 1500 I.U. in $15 \mathrm{ml}$ of buffered saline (PBS) (Phosphate buffered saline - Sigma, Saint Louis, Missouri, USA).

Isolation of neutrophils

Hypotonic erythrocyte lysis (Carlson and Kaneko 1973): Heparinized blood was exposed to hypotonic conditions for 40 seconds. During this time, $50 \mathrm{ml}$ of heparinized blood was mixed with $100 \mathrm{ml}$ of redistilled water. Then $50 \mathrm{ml}$ of $2.7 \% \mathrm{NaCl}$ solution was added for the restoration of the standard osmotic pressure. This was followed by a 10-min centrifugation period, in which one of two variant techniques was always used: at the centrifugal force of $200 \mathrm{~g}$ - the "gentle" variant and at $1000 \mathrm{~g}$ - the "rough" variant). After the centrifugation, the supernatant was decanted and $50 \mathrm{ml}$ of PBS were added. The procedure was then repeated starting from the erythrocyte lysis up to the centrifugation. In both variant techniques, the material was subsequently resuspended in PBS, centrifuged at $200 \mathrm{~g}$ again and resuspended in RPMI-1640 (Sigma, Saint Louis, Missouri, USA).

FACS Lysing Solution (Hodge et al. 1999): A blood sample $(500 \mu \mathrm{l})$ was mixed with working solution of Annexin-V and PI and, after $15 \mathrm{~min}$, it was kept in the dark at room temperature. After adding 2 ml of FACS Lysing Solution (Becton Dickinson Biosciences, San Jose, California, USA), the sample was resuspended and centrifuged 
for $5 \mathrm{~min}$ at $500 \mathrm{~g}$. Then the supernatant was decanted and $2 \mathrm{ml}$ of PBS were added. New 5 -min centrifugation at $500 \mathrm{~g}$ followed, the supernatant was removed and the sediment was resuspended in $500 \mu \mathrm{l}$ of RPMI-1640.

Both techniques were carried out at laboratory temperature $\left(20\right.$ to $\left.23^{\circ} \mathrm{C}\right)$.

Methods for detecting apoptosis and necrosis

Light microscopy: Smears of the cell suspension in RPMI were prepared by applying $10 \mu \mathrm{l}$ of the suspension and $10 \mu \mathrm{l}$ of autologous bovine serum. Slides stained by the Pappenheim method (May-Grünwald, GiemsaRomanowski stain) were examined by light microscopy with oil immersion (Olympus BH2, Olympus Optical Co., LTD, Tokyo, Japan). Apoptosis and necrosis of isolated neutrophils were assessed by the enumeration of at least 200 neutrophils according to morphological features previously described (Sládek and R yšánek 2000).

Flow cytometry: Apoptotic and necrotic neutrophils were analysed by FCM after simultaneous staining with Annexin-V labelled with fluorescein isothiocyanate (FITC) plus propidium iodide (PI) as described by V ermes et al. (1995). The commercial AnnexinV-FLUOS Staining Kit (Boehringer Mannheim, GmbH, Mannheim, Germany) was used according to the manufacturer's instructions in the procedure described below.

The cell suspension was adjusted to $1 \cdot 10^{6}$ per $1 \mathrm{ml}$ in $100 \mathrm{ml}$ of fresh incubation buffer containing FITCAnnexin-V and PI, and the suspension was analysed after 15-min incubation at room temperature by FCM (FACS Calibur apparatus, Beckton Dickinson, Mountain View, California, USA) by differentiating at least 10000 cells. The neutrophil region was gated in accordance with procedure published V an Oostveldt et al. (1999). Dot plots were evaluated qualitatively and quantitatively using the WinMDI 2.8 software (Trotter 2000).

\section{Statistics}

The proportions of apoptotic and necrotic neutrophils from blood of the four heifers are shown as arithmetic means and standard deviations. The normality of a data distribution was proved by Kolmogorov test. The statistical significance of differences in the proportion of apoptotic and necrotic neutrophils were determined by the $t$-test. The data were processed by the STAT Plus software (Matoušková et al. 1992).

\section{Results}

Two methods of erythrocyte lysis were used in the study: hypotonic lysis in two variants differing in the centrifugal force (expressed in $g$ - gravity force units) applied in the centrifugation after the erythrocyte lysis proper, namely $200 \mathrm{~g}$ and $1000 \mathrm{~g}$, and erythrocyte lysis with FACS Lysing Solution. The analysis of neutrophils using FCM and morphological methods showed significant differences, particularly in the cell yield and in the proportion of apoptotic and necrotic cells detected.

\section{Neutrophil yield}

The FCM evaluation showed a statistically highly significant difference $(P<0.01)$ in the neutrophil yield (percentage of neutrophils in total leukocytes) between the method with FACS Lysing Solution (ca 30\%) and the hypotonic lysis (ca 40\%) (Table 1). In contrast, the light microscopy failed to show any significant difference in neutrophil yields between the above-stated methods (Table 2). The relatively low yield improved when the cell adhesion technique was applied (Table 5). The neutrophil yield was significantly higher on the adhesion assay slides (hypotonic lysis plus "gentle" centrifugation: $90.64 \pm 4.49 \%$, hypotonic lysis plus "rough" centrifugation: $90.49 \pm 4.25 \%$ ) than on the smears (hypotonic lysis plus "gentle" centrifugation: $33.25 \pm 4.40 \%$, hypotonic lysis plus "rough" centrifugation: $33.30 \pm 13.86 \%)(P<0.01)$.

In this evaluation of isolated neutrophils obtained by both methods, cells were analysed that showed biochemical and morphological features specific for apoptosis.

\section{Biochemical and morphological features of apoptotic neutrophils}

Apoptotic neutrophils were detected with both the FCM and the light microscopy methods.

In the dot plots obtained in FCM analysis after staining with Annexin-V plus PI, the neutrophils formed three subregions spaced in three quadrants: normal neutrophils (Annnexin-V negative/PI negative) took up the lower left quadrant, apoptotic neutrophils (Annexin-V positive/PI negative) took the lower right quadrant and the necrotic ones (Annexin-V positive/PI positive) were in the upper right quadrant (Fig. 1 a, b). 
Table 1. Proportions of apoptosis and necrosis in bovine neutrophil granulocytes after isolation from blood. Flow cytometry (Annexin-V/propidium iodide).

\begin{tabular}{|c|c|c|c|c|c|c|c|}
\hline & \multicolumn{2}{|c|}{$\begin{array}{c}\text { FACS Lysing } \\
\text { Solution }^{\text {a }}\end{array}$} & \multicolumn{2}{|c|}{$\begin{array}{l}\text { Centrifugation } \\
200 g^{\mathrm{b}}\end{array}$} & \multicolumn{2}{|c|}{$\begin{array}{c}\text { Centrifugation } \\
1000 \mathrm{~g}^{\mathrm{c}}\end{array}$} & \multirow[t]{2}{*}{ Significance } \\
\hline & $\begin{array}{c}\text { Arithmetic } \\
\text { mean }\end{array}$ & S.D. & $\begin{array}{l}\text { Arithmetic } \\
\text { mean }\end{array}$ & S.D. & $\begin{array}{l}\text { Arithmetic } \\
\text { mean }\end{array}$ & S.D. & \\
\hline $\begin{array}{l}\text { Neutrophils } \\
{[\%]}\end{array}$ & 32.13 & 3.63 & 42.39 & 4.24 & 38.37 & 4.14 & $\begin{array}{l}++a: b \\
++a: c\end{array}$ \\
\hline $\begin{array}{l}\text { Apoptotic } \\
\text { neutrophils - } \\
\text { An.-V+/PI- [\%] }\end{array}$ & 5.36 & 2.15 & 42.14 & 7.12 & 49.00 & 14.70 & $\begin{array}{l}++^{a: b} \\
++^{a: c}\end{array}$ \\
\hline $\begin{array}{l}\text { Necrotic } \\
\text { neutrophils - } \\
\text { An.-V+/PI+ [\%] }\end{array}$ & 0.51 & 0.12 & 41.12 & 5.55 & 36.91 & 24.38 & $\begin{array}{l}+++^{a: b} \\
++^{a: c}\end{array}$ \\
\hline
\end{tabular}

$+P<0.05 ;++P<0.01$

An.-V+: Annexin V positivity; PI-: propidium iodide negativity; PI+: propidium iodide positivity.

The proportions of apoptotic and necrotic neutrophils stated in the table were been calculated from the total count of neutrophils.

Table 2. Proportions of apoptosis and necrosis in bovine neutrophil granulocytes after isolation from blood.

Light microscopy - smears.

\begin{tabular}{|c|c|c|c|c|c|c|c|}
\hline & \multicolumn{2}{|c|}{$\begin{array}{c}\text { FACS Lysing } \\
\text { Solution }^{\text {a }}\end{array}$} & \multicolumn{2}{|c|}{$\begin{array}{c}\text { Centrifugation } \\
200 \mathrm{~g}^{\mathrm{b}}\end{array}$} & \multicolumn{2}{|c|}{$\begin{array}{l}\text { Centrifugation } \\
1000 \mathrm{~g}^{\mathrm{c}} \\
\end{array}$} & \multirow{2}{*}{ Significance } \\
\hline & $\begin{array}{l}\text { Arithmetic } \\
\text { mean }\end{array}$ & S.D. & $\begin{array}{l}\text { Arithmetic } \\
\text { mean }\end{array}$ & S.D. & $\begin{array}{l}\text { Arithmetic } \\
\text { mean }\end{array}$ & S.D. & \\
\hline Neutrophils [\%] & 36.27 & 4.19 & 33.25 & 4.40 & 33.30 & 13.86 & - \\
\hline $\begin{array}{l}\text { Apoptotic } \\
\text { neutrophils [\%] }\end{array}$ & 1.92 & 1.74 & 9.43 & 3.69 & 12.60 & 4.35 & $\begin{array}{l}++a: b \\
++a: c\end{array}$ \\
\hline $\begin{array}{l}\text { Necrotic } \\
\text { neutrophils [\%] }\end{array}$ & 1.05 & 0.76 & 12.67 & 4.74 & 14.96 & 12.64 & $\begin{array}{l}++a: b \\
+a: c\end{array}$ \\
\hline
\end{tabular}

$+P<0.05 ;++P<0.01$

The numbers of apoptotic and necrotic neutrophils stated in the table were calculated from the total count of neutrophils.

Table 3. Proportions of apoptosis and necrosis in bovine neutrophil granulocytes after isolation from blood. Light microscopy - adhesion slides.

\begin{tabular}{|l|c|c|c|c|c|}
\hline & \multicolumn{2}{|c|}{$\begin{array}{c}\text { Centrifugation } \\
200 \mathrm{~g}^{\mathrm{b}}\end{array}$} & \multicolumn{2}{c|}{$\begin{array}{c}\text { Centrifugation } \\
1000 \mathrm{~g}^{\mathrm{c}}\end{array}$} & \multirow{2}{*}{ Significance } \\
\cline { 2 - 5 } & $\begin{array}{c}\text { Arithmetic } \\
\text { mean }\end{array}$ & S.D. & $\begin{array}{c}\text { Arithmetic } \\
\text { mean }\end{array}$ & S.D. & \\
\hline Neutrophils [\%] & 90.64 & 4.49 & 90.49 & 4.25 & - \\
\hline $\begin{array}{l}\text { Apoptotic } \\
\text { neutrophils [\%] }\end{array}$ & 3.77 & 2.23 & 3.21 & 2.60 & - \\
\hline $\begin{array}{l}\text { Necrotic } \\
\text { neutrophils [\%] }\end{array}$ & 2.88 & 1.30 & 3.04 & 2.25 & - \\
\hline
\end{tabular}

$+P<0.05 ;++P<0.01$

Proportions of apoptotic and necrotic neutrophils shown in the table were calculated from the total count of neutrophils.

Detailed analysis of the suspension of isolated neutrophils in the light microscopy showed apoptotic neutrophils that occurred in three structurally different stages. These stages were 

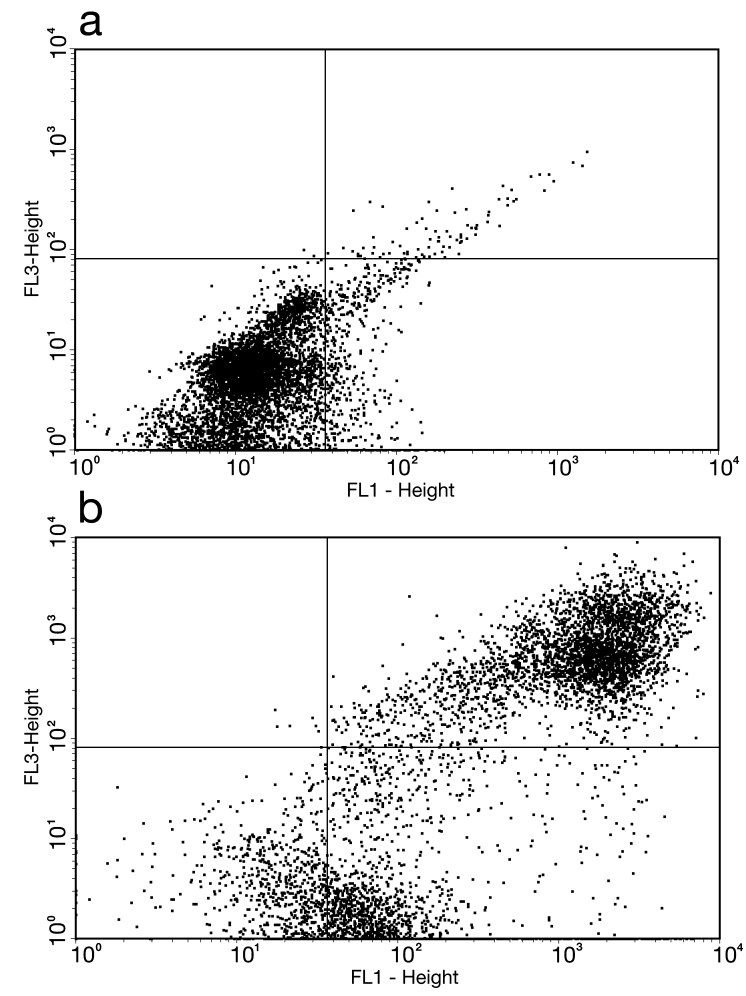

Fig. 1. After staining with Annexin-V plus propidium iodide, the neutrophils formed three subregions spaced in three quadrants in FCM dot-plots: normal neutrophils (An.-V-/PI-) took the lower left quadrant, apoptotic neutrophils (An.-V+/PI-) the lower right quadrant and the necrotic neutrophils $(\mathrm{An} .-\mathrm{V}+/ \mathrm{PI}+)$ took the upper right quadrant. An.-V + : Annexin V positivity; PI-: propidium iodide negativity; PI + : propidium iodide positivity.

a: FACS Lysing Solution

b: hypotonic lysis

Table 4. The effect of adherence technique on the proportions of apoptosis in bovine blood neutrophils. Light microscopy.

\begin{tabular}{|c|c|c|c|c|c|}
\hline & \multicolumn{2}{|c|}{ Adhesion slides a } & \multicolumn{2}{|c|}{ Smears ${ }^{b}$} & \multirow[b]{2}{*}{ Significance } \\
\hline & $\begin{array}{l}\text { Arithmetic } \\
\text { mean }\end{array}$ & S.D. & $\begin{array}{l}\text { Arithmetic } \\
\text { mean }\end{array}$ & S.D. & \\
\hline $\begin{array}{l}\text { Centrifugation } \\
\text { at } 200 \mathrm{~g}\end{array}$ & 3.77 & 2.23 & 9.43 & 3.69 & $++a: b$ \\
\hline $\begin{array}{l}\text { Centrifugation } \\
\text { at } 1000 \mathrm{~g}\end{array}$ & 3.21 & 2.60 & 12.60 & 4.35 & $++\mathrm{a}: \mathrm{b}$ \\
\hline
\end{tabular}

$+P<0.05 ;++P<0.01$

Proportions of apoptotic neutrophils (\%) shown in the table were calculated from the total count of neutrophils.

karyopyknosis, zeiosis and the stage of apoptotic bodies. A reduction in nucleus size, chromatin condensation and the loss of pseudopodia were typical of karyopyknosis (Plate I, Fig. 2). Zeiosis was manifested as the blebbing of the cytoplasmic membrane; the cells took 
Table 5. The effect of adherence technique on the yield of bovine blood neutrophils. Light microscopy.

\begin{tabular}{|c|c|c|c|c|c|}
\hline & \multicolumn{2}{|c|}{ Adhesion slides a } & \multicolumn{2}{|c|}{ Smears ${ }^{b}$} & \multirow[b]{2}{*}{ Significance } \\
\hline & $\begin{array}{l}\text { Arithmetic } \\
\text { mean }\end{array}$ & S.D. & $\begin{array}{l}\text { Arithmetic } \\
\text { mean }\end{array}$ & S.D. & \\
\hline $\begin{array}{l}\text { Centrifugation } \\
\text { at } 200 \mathrm{~g}\end{array}$ & 90.64 & 4.49 & 33.25 & 4.40 & $++\mathrm{a}: \mathrm{b}$ \\
\hline $\begin{array}{l}\text { Centrifugation } \\
\text { at } 1000 \mathrm{~g}\end{array}$ & 90.49 & 4.25 & 33.30 & 13.86 & $++a: b$ \\
\hline
\end{tabular}

$+P<0.05 ;++P<0.01$

Proportions of neutrophils (\%) shown in the table were calculated from the total count of leukocytes.

a foamy or honeycomb appearance (Plate I, Fig. 3). The next stage was manifested as the formation of cell fragments of various sizes: the apoptotic bodies (Fig. 4).

On the basis of the abovementioned biochemical and morphological features, the proportions of apoptotic neutrophils were determined using FACS and light microscopy in the particular isolation methods used.

Flow cytometry analysis

The results obtained in FCM make it obvious that the method with the FACS Lysing Solution affected the neutrophil viability to the least extent when the afore-mentioned isolation techniques are considered. The FCM method resulted in $5.36 \pm 2.15 \%$ of apoptotic and $0.51 \pm 0.12 \%$ of necrotic neutrophils, which means that Annexin-V positivity was established in a total of $5.87 \%$ isolated neutrophils. When the hypotonic-lysis method was used (Table 1), 83.26\% and $85.91 \%$ Annexin-V positive neutrophils were found after the "gentle" and after the "rough" centrifugation, respectively.

\section{Light microscopy analysis}

When the hypotonic lysis and the FACS Lysing Solution methods were compared, it was established that the FACS Lysing Solution method impaired the neutrophil viability the least $(1.92 \pm 1.74 \%$ of apoptotic and $1.05 \pm 0.76 \%$ of necrotic neutrophils). Hypotonic lysis and "gentle" centrifugation showed a more marked damage to neutrophil viability $(9.43 \pm 3.69 \%$ of apoptotic and $12.67 \pm 4.74 \%$ of necrotic cells), while the "rough" centrifugation resulted in the highest proportion of apoptotic and necrotic neutrophils (12.60 $\pm 4.35 \%$ and 14.96 $\pm 12.64 \%$ respectively) (Table 2 ).

Surprisingly, statistically significant differences in the proportion of apoptotic neutrophils on the smears as compared with the adherent fraction were observed $(P<0.01)$. As the Tables 3 and 4 show, the proportion of apoptotic neutrophils was $3-4$ times higher on the smears than on the adhesion slides.

A comparison of biochemical and morphological features of apoptosis in bovine blood neutrophils in the flow cytometer and in the light microscope is shown in Table 6.

\section{Discussion}

The objective of this work was to establish whether the technique of erythrocyte lysis causes biochemical and morphological changes typical of neutrophil apoptosis and necrosis. Methods of FCM and light microscopy were used for this purpose.

For the isolation of the blood neutrophils, the technique specially developed for FCM was used, namely the method with FACS Lysing Solution, in addition to the erythrocyte 
Table 6. Comparison of biochemical and morphological features of bovine blood neutrophils apoptosis in a flow cytometry and in a light microscopy (smears).

\begin{tabular}{|c|c|c|c|c|c|}
\hline & \multicolumn{2}{|c|}{ Flow cytometer $^{\mathrm{a}}$} & \multicolumn{2}{|c|}{ Light microscopy $^{b}$} & \multirow[b]{2}{*}{ Significance } \\
\hline & $\begin{array}{l}\text { Arithmetic } \\
\text { mean }\end{array}$ & S.D. & $\begin{array}{c}\text { Arithmetic } \\
\text { mean }\end{array}$ & S.D. & \\
\hline $\begin{array}{l}\text { FACS Lysing } \\
\text { Solution }\end{array}$ & 5.36 & 2.15 & 1.93 & 1.74 & $++a: b$ \\
\hline $\begin{array}{l}\text { Centrifugation } \\
\text { at } 200 \mathrm{~g}\end{array}$ & 42.14 & 7.12 & 9.43 & 3.69 & ++ a:b \\
\hline $\begin{array}{l}\text { Centrifugation } \\
\text { at } 1000 \mathrm{~g}\end{array}$ & 49.00 & 14.70 & 12.60 & 4.35 & $++a: b$ \\
\hline
\end{tabular}

$+P<0.05 ;++P<0.01$

Proportions of apoptotic neutrophils (\%) shown in the table were calculated from the total count of neutrophils. Flow cytometry - apoptotic neutrophils are Annexin-V and propidium iodide positive. Light microscopy - neutrophils with morphological features of apoptosis.

hypotonic lysis. The FACS Lysing Solution method has been commonly used for the isolation of leukocytes for subsequent analysis in FCM (Chen et al. 1996; B os suyt et al. 1997; Macey et al. 1997; Carulli et al. 1998; Tay et al. 1998; Hodge et al. 1999; Storie et al. 2003). These methods have been chosen because the lysis of erythrocytes is most often used for the isolation of neutrophils. Moreover, one can expect marked effect on the biochemical properties of neutrophils thus isolated, as mentioned below.

The effectiveness of the isolation technique is connected with the cell yield in particular. In this work, FCM established a highly significant difference in neutrophil yield between the method based on hypotonic solution and the method with FACS Lysing Solution, in which the yield was higher. When the light microscope was used, the difference in neutrophil yield between both methods could not be observed, however. This discrepancy was probably caused by the evaluation technique. In the light microscope, "only" 200 neutrophils were evaluated while in the FCM this cell number amounted to twenty thousand.

Two variants of the hypotonic-lysis methods were used, differing in the force $g$ used for the centrifugation after the erythrocyte lysis. This was done in order to establish whether the higher centrifugal force $(1000 \mathrm{~g})$ markedly increased the neutrophil yield and whether it physically altered the cells. This hypothesis was not confirmed, however, as documented by the results obtained in FCM and in the light microscopy. Surprisingly, the use of higher $g$ resulted in a lower yield of neutrophils as measured by FCM. This was probably caused by a shift of altered neutrophils from the neutrophil region into the debris region seen in the dot plots.

It has been known that the isolation techniques can induce changes that result in cell death (Van Oostveldt et al. 1999). Apoptosis is the programmed cell death, which is characterised by specific biochemical and structural changes (Kerr and Searle 1973). It is interesting that biochemical changes precede structural changes. One of the techniques used for the detection of apoptosis and necrosis of isolated blood cells in suspension is the FCM after labelling the cells with Annexin-V plus propidium iodide according to Vermes et al. (1995).

During apoptosis, alterations on the cell surface appear first. One of these is the translocation of phosphatidylserine from the inside to the outside of the cytoplasmic membrane. Annexin-V has a high affinity to phosphatidylserine; therefore it is used for the detection of apoptotic cells (Fad ok 1992). The translocation of phosphatidylserine to the 
cell surface is not specific to apoptosis only, but it also occurs during necrosis. Propidium iodide is a nuclear stain for which the cytoplasmic membrane of both living and apoptotic cells is not permeable, and thus it is suitable for the discrimination between apoptosis and necrosis (Vermes et al. 1995).

Following the translocation of phosphatidylserine in apoptotic cells, further changes appear that can be detected with morphological methods. These changes include karyopyknosis, zeiosis, cell shrinkage and its fragmentation into apoptotic bodies. Despite the fact that the microscopy is not a quick and automated technique, it remains the "gold standard" for the assessment of viability loss of blood cells (Hodge et al. 1999) as it reveals the signs of granulocyte apoptosis in anticoagulated blood (S a vill et al. 1993). That is why both above-mentioned detection techniques were used in this work and why this is the first paper in the field of veterinary haematology describing the effects of isolation methods not only on the biochemistry but also on the morphological manifestations of apoptotic neutrophils.

We can thus state that both isolation techniques caused some damage to the neutrophils, manifested as apoptosis and necrosis of some cells. Statistically significant differences were found between both methods of isolation and between the methods of apoptosis detection. The results imply that the method based on the FACS Lysing Solution is a gentler technique of neutrophil isolation compared with the hypotonic lysis. Its effect on the Annexin$\mathrm{V}$ positivity of isolated neutrophils is almost negligible (5\%). Considering that normal full blood contains around 2\% of Annexin-V positive neutrophils (Van Oostveldt et al. 1999), it is obvious that this technique is not involved in immediate cell alteration. Also, morphological signs of neutrophil apoptosis were observed only in a very small part of the cells (ca 2\%). In contrast, when the hypotonic lysis technique was used, the proportion of Annexin-V positive neutrophils and morphologically altered cells observed was higher and the difference was statistically significant.

In accordance with statements of Hodge et al. (1999) the FACS Lysing Solution used in our experiments provides not only complete lysis of erythrocytes, but also fixation of cell membrane of other cells by the fixation compounds including formaldehyde and diethylene glycol in the same time.

Van Oostveldt et al. (1999) have used the FCM method with Annexin-V plus propidium iodide for the detection of apoptosis and necrosis of isolated neutrophils. They have observed $87.3 \%$ of Annexin-V positive neutrophils after the isolation by hypotonic erythrocyte lysis. This result is almost identical with that of our experiments with hypotonic erythrocyte lysis and "gentle" centrifugation, which corresponds to the method used by V an Oostveldt et al. (1999). Annexin-V positive neutrophils are apoptotic and necrotic neutrophils, thus this value comprises apoptotic neutrophils $(42.14 \pm 7.12 \%)$ plus necrotic neutrophils $(41.12 \pm 5.55 \%)$. In our study, we have extended the above-mentioned data by the analysis of apoptotic neutrophils with methods of ligh microscopy.

It could seem that there is a discrepancy between the results obtained in the evaluation of the cell population by FCM on the one hand, and the results obtained by light microscopy on the other hand. The results obtained by FCM with Annexin-V plus propidium iodide staining show a higher proportion of apoptotic neutrophils than in the results obtained by light microscopy $(P<0.01)$. However, this fact is substantiated. The dynamics of the apoptotic process include an early stage, characterised by translocation of phosphatidylserine from the outer to the inner side of the cytoplasmic membrane (Vermes et al. 1995). On the other hand, light microscopy detects morphological changes taking place subsequently after the stated biochemical changes of cell receptors (Martin et al. 1995). This implies that both detection methods should be used in the analysis of cellular apoptosis if both the early and the late stages of apoptosis are to be detected. 
Because the yield of neutrophils is relatively low, we tried to increase it by using the cell adherence technique besides the blood smears. The adhesion slides showed a markedly higher neutrophil yield in comparison with the smears. The ninety-percent proportion of neutrophils suggests a higher adherence capacity of these cells in comparison with other leukocytes, which confirms the present authors' earlier finding (Ryšánek et al. 2001). Using hypotonic erythrocyte lysis according to Carlson and Kaneko (1973), they attained a yield of $89.9 \%$ of neutrophils isolated and adhered to the microscopic slide. The results obtained by FCM and by light microscopy (smears) make it apparent that the yield of neutrophils corresponded to the physiological range of neutrophil proportion in blood leukocyte differential count as reported by Kramer (2000): 15 - 45\% of neutrophils in bovine blood.

An interesting finding is the detection of a markedly lower percentage of apoptotic neutrophils $(P<0.01)$ found on the adhesion slides in comparison with that on the smears. This fact is, however, not so much surprising, because it is caused by the different functional properties of apoptotic neutrophils. As it has been known from the literature (Why te et al. 1993), apoptotic neutrophils have impaired functional properties (cytoskeletal functions, chemotaxis, phagocytosis, degranulation). Greenstein et al. (2000) have reported that decreasing functional activities of neutrophils (including the lower adhesion capacity on epithelial cells) correlates with their apoptosis. Apoptosis of neutrophils is associated with changes at the level of crucial surface receptors, which mediate the adhesion of neutrophils (Dransfield et al. 1995).

In conclusion and on the basis of the results, the methods for the isolation of blood neutrophils can be evaluated with regard to their suitability for subsequent in vitro studies: The methods of hypotonic erythrocyte lysis have the disadvantage that the neutrophils (leukocytes) are first isolated and only then the experimental intervention can be performed. Another disadvantage is the demands on time and the need for a large amount of blood, which makes this method inapplicable in small laboratory animals. As documented by the FCM analysis and light microscopy, neutrophils markedly altered by this procedure can load the subsequent studies with a great error. On the contrary, the method with FACS Lysing Solution is very gentle and it allows experimental interventions to be applied first, and only then the neutrophils can be isolated. This leukocyte isolation is very quick and suitable for the purposes of FCM measurements. We must note, however, that no leukocyte isolation method can fully eliminate its effects of neutrophil viability.

\section{Vliv izolačních technik na životnost neutrofilů krve skotu}

Byl posouzen vliv vybraných izolačních technik na životnost neutrofilních granulocytů (neutrofilů) krve klinicky zdravých jalovic, kř́ǐ̌enek holštýnského a českého strakatého plemene. Byly použity dvě metody izolace krevních neutrofilů: izolace neutrofilů hypotonickou lýzou erytrocytů (ve dvou variantách - dle gravitační síly při odstředění po vlastní lýze erytrocytů: $200 \mathrm{~g}$ a $1000 \mathrm{~g}$ ) a izolace neutrofilů lytickým činidlem FACS Lysing Solution. Životnost izolovaných neutrofilů byla hodnocena detekcí apoptózy a nekrózy těchto buněk. Z výsledků získaných průtokovým cytometrem (FCM) bylo zjištěno, že z použitých izolačních technik nejméně snižuje životnost neutrofilů metoda s FACS Lysing Solution. Při této metodě bylo z celkového podílu neutrofilů apoptotických 5,36 $\pm 2,15 \%$ a nekrotických $0,51 \pm 0,12 \%$. Oproti tomu prri izolaci neutrofilů hypotonickou lýzou erytrocytů vykazovala populace neutrofilů výrazně vyšší zastoupení apoptotických a nekrotických buněk $(42,14 \pm 7,12 \%$, respektive $49,00 \pm 14,70 \%$ apoptotických neutrofilů a $41,12 \pm 5,55 \%$, respektive $36,91 \pm 24,38 \%$ nekrotických neutrofilů; $P<0.01$ ). To rovněž potvrzuje světelná mikroskopie. Z neutrofilů izolovaných pomocí FASC Lysing Solution bylo $1,92 \pm 1,74 \%$ apoptotických a $1,05 \pm 0,76 \%$ nekrotických, na rozdíl od hypotonické 
lýzy erytrocytů: 9,43 $\pm 3,69 \%$ apoptotických, 12,67 $\pm 4,74 \%$ nekrotických neutrofilů (při odstředování s $200 \mathrm{~g}$ ), respektive $12,60 \pm 4,35 \%$ apoptotických, 14,96 $\pm 12,64 \%$ nekrotických neutrofilů (při odstředování s $1000 \mathrm{~g}$ ). Z uvedeného vyplývá, že hypotonická lýza není vhodnou metodou pro izolaci neutrofilů, nebot metoda sama výrazně ovlivňuje životnost buněk.

\section{Acknowledgements}

This study was supported by Grant Agency of the Czech Republic (GACR No. 524/03/1531). We thank Mrs Michaela Knakalova for her excellent technical assistance.

\section{References}

ARENDS MJ, MORRIS RG, WYLLIE AH 1990: Apoptosis: the role of endonuclease. Amer J Pathol 136: 593-608

BOSSUYT X, MARTI GE, 1997: Comparative analysis of whole blood lysis methods for flow cytometry. Cytometry 30: 124-133

BOYUM A 1968: Isolation of mononuclear cells and granulocytes from human peripheral blood. Scand J Clin Lab Invest 21: 77-89

CARLSON GP, KANEKO JJ 1973: Isolation of leukocytes from bovine peripheral blood. Proc Soc Exp Biol Med 142: $853-856$

CARULli G, SBRANA S, AZZARA A, MINNUCCI S, ANGIOLINI C, MARINI A, AMBROGI F 1998: Detection of eosinophils in whole blood samples by flow cytometry. Cytometry 34: 272-279

CHEN WY, LEI HY, WANG JY, LU CC 1996: Direct measurement of neutrophil F-actin content in microvolume whole blood samples. Int Arch Allergy Immunol 110: 325-331

COWLAND JB, BORREGAARD N 1999: Isolation of neutrophil precursors from bone marrow for biochemical and transcriptional analysis. J Immunol Method 232: 191-200

DELVECCHIO MT, LEONCINI L, BUERKI K, KRAFT R, MEGHA T, BARBINI P, TOSI P, COTTIER T 1993: Diffuse centrocytic and/or centroblasticmalignant non-Hodgkin's lymphomas: comparison of mitotic and pyknotic (apoptotic) indices. Int J Cancer 124: 116- 121

DRANSFIELD I, STOCKS SC, HASLETT C 1995: Regulation of cell adhesion molecule expression and function associated with neutrophil apoptosis. Blood 85: 3264- 3273

DUQUE RE, PHAN SH, HUDSON JL, TILL GO, WARD PA 1985: Functional defects in phagocytic cells following thermal injury. Application of flow cytometric analysis. Amer J Pathol 118: 116- 127

FADOK VA, VOELKER DR, CAMPBELL PA, COHEN JJ, BRATTON DL, HENSON PM 1992: Exposure of phosphatidylserine on the surface of apoptotic lymphocytes triggers specific recognition and removal by macrophages. J Immunol 148: 2207-2216

GRANVILLE DJ, CARTHY CM, HUNT DW, MCMANUS BM 1998: Apoptosis: molecular aspects of cell death and disease. Lab Invest 78: 893-913

GREENSTEIN, S. BARNARD, J, ZHOU, K, FONG, M, HENDEY, B, 2000: Fas activation reduces neutrophil adhesion to endothelial cells. J Leukocyte Biol 68: 715-722

HALLEN-SANDGREN C, BJORK I 1988: A rapid technique for the isolation of highly purified, functionally intact bovine neutrophilic granulocytes. Vet Immunol Immunop 18: 81-94

HODGE GL, FLOWER R, HAN P 1999: Optimal storage conditions for preserving granulocyte viability as monitored by Annexin V binding in whole blood. J Immunol Method 225: 27-38

JUNQUEIRA LC, CARNEIRO J, KELLEY RO 1997: Základy histologie. H a H, Praha, 502 p.

KERR JF, SEARLE J 1973: Deletion of cells by apoptosis during castration-induced involution of the rat prostate. Virchows Arch B Cell Pathol 13: 87-102

KRAMER JW 2000: Normal haematology of cattle, sheep and goats. In: FELDMAN BF, ZINKL JG, JAIN NC (Eds). Schalm's veterinary haematology. Williams and Wilkins, Philadelphia, pp. 1075-1084.

KUIJPERS TW, ROOS D 2001: Neutrophils. In: Encyklopedia of life sciences. Nature Publishing Group,

MACEY MG, MCCARTHY DA, VAN AGTHOVEN A, NEWLAND AC 1997: How should CD34+ cells be analysed? A study of three classes of antibody and five leucocyte preparation procedures. J Immunol Method 204: $175-188$

MARTIN SJ, REUTELINGSPERGER CP, MCGAHON AJ, RADER JA, VAN SCHIE RC, LAFACE DM, GREEN DR 1995: Early redistribution of plasma membrane phosphatidylserine is a general feature of apoptosis regardless of the initiating stimulus: inhibition by overexpression of Bcl- 2 and Abl J Exp Med 182: 1545-1556

MATOUŠKOVÁ O, CHALUPA J, CÍGLER M, HRUŠKA K 1992: STAT Plus - Manual. Veterinary Research Institute, Brno, 168 p.

PAAPE MJ, BANNERMAN DD, ZHAO X, LEE JW 2003: The bovine neutrophil: Structure and function in blood and milk. Vet Res 34: 597-627

REED JC 2000: Mechanisms of apoptosis. Amer J Pathol 157: 1415- 1430 
ROETS E, BURVENICH C, DIEZ-FRAILE A, NOORDHUIZEN-STASSEN EN 1999: Evaluation of the role of endotoxin and cortisol on modulation of CD18 adhesion receptors in cows with mastitis caused by Escherichia coli. Amer J Vet Res 60: 2-9

RYŠÁNEK D, BABÁK V, SLÁDEK Z, TOMAN M 2001: Variations among unbred heifers in the activities of polymorphonuclear leucocytes from the mammary gland and blood. J Vet Med B 48: 31-41

SAVILL JS, FADOK V, HENSON PM, HASLETT C 1993: Phagocytic recognition of cells undergoing apoptosis. Immunol Today 14: 131-139

SLÁDEK Z, RYŚÁNEK D 2000: Morphology of apoptosis of polymorphonuclear leukocytes isolated from mammary glands of unbred heifers. Vet Med-Czech 45: 71-81

SMITH DL, ROMMEL F 1977: A rapid micro method for the simultaneous determination of phagocyticmicrobiocidal aktivity of human peripheral blood leukocytes in vitro. J Immunol Method 17: 241-247

SMITH GS 2000: Neutrophils. In: FELDMAN BF, ZINKL JG, JAIN NC (Eds): Schalm's veterinary haematology. Williams and Wilkins, Philadelphia, pp. 281-296.

SOLTYS J, SWAIN SD, SIPES KM, NELSON LK, HANSON AJ, KANTELE JM, JUTILA MA QUINN MT 1999: Isolation of bovine neutrophils with biomagnetic beads: comparison with standard Percoll density gradient isolation methods. J Immunol Method 226: 71-84

STORIE I, SAWLE A, GOOGFELLOW K, WHITBY L, GRANGER V, REILLY JT, BARNETT D 2003: Flow rate calibration I: a novel approach for performing absolute cell counts. Cytometry B Clin Cytom 55: 1-7

TAY SP, CHEONG SK, HAMIDAH NH, AINOON O 1998: Flow cytometric analysis of intracellular myeloperoxidase distinguishes lymphocytes, monocytes and granulocytes. Malays J Pathol 20: 91-94

TROTTER J 2000: WinMDI Version 2.8.

VAN OOSTVELDT K, DOSOGNE H, BURVENICH C, PAAPE MJ, BROCHEZ V, VAN DEN EECKHOUT E 1999: Flow cytometric procedure to detect apoptosis of bovine polymorphonuclear leukocytes in blood. Vet Immunol Immunop 70: 125-133

VERMES I, HAANEN C, STEFFENS-NAKKEN H, REUTELINGSPERGER C 1995: A novel assay for apoptosis. Flow cytometric detection of phosphatidylserine expression on early apoptotic cells using fluorescein labelled Annexin V. J Immunol Method 184: 39-51

WHYTE MK, MEAGHER LC, MACDERMOT J, HASLETT, C 1993: Impairment of function in aging neutrophils is associated with apoptosis. J Immunol 150: 5124-5134 
Plate I

Sláma P. et al.: Effect of Isolation ... pp. 343-354
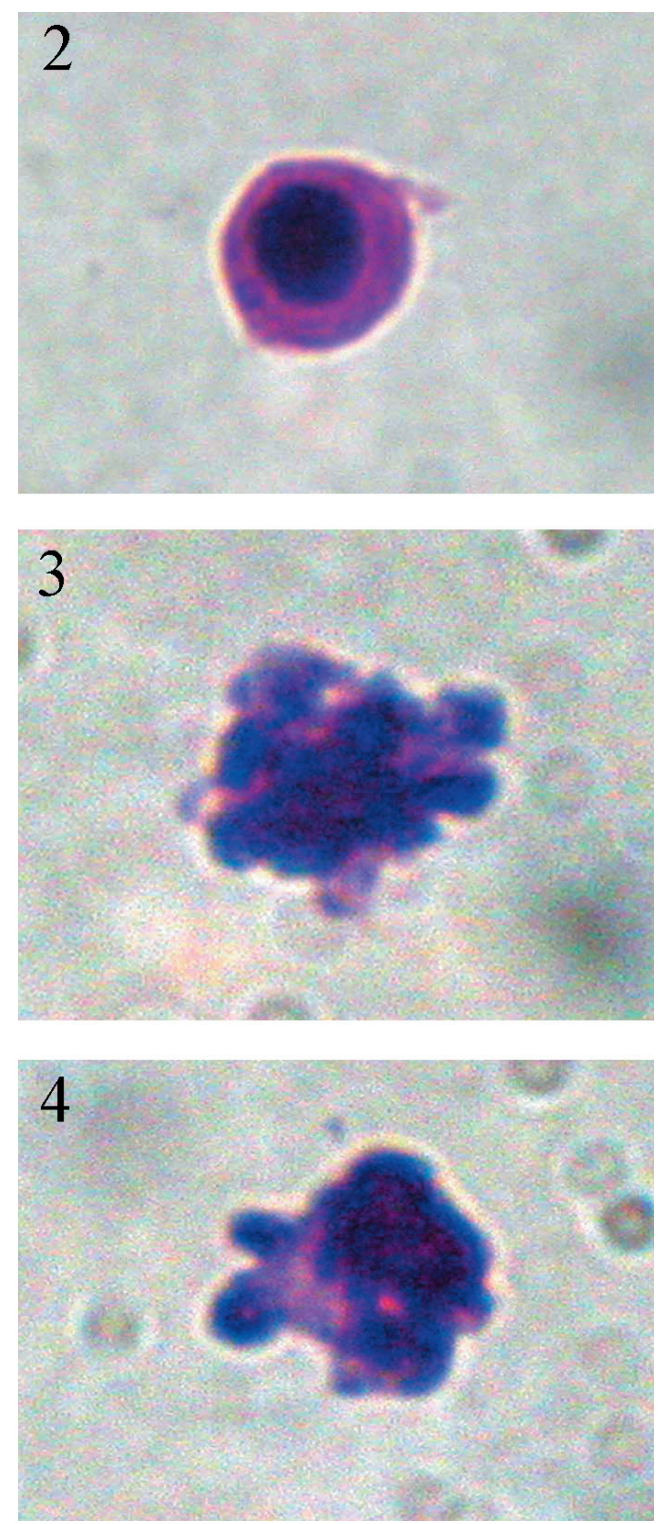

Fig. 2. Light microscopy of a bovine blood neutrophil undergoing karyopyknosis. Magnification $\times 1000$. Fig. 3. Light microscopy of a bovine blood neutrophil undergoing zeiosis. Magnification $\times 1000$.

Fig. 4. Light microscopy of a bovine blood neutrophil forming an apoptotic body. Magnification $\times 1000$. 